\title{
The factors determining the service lenght of the lead refining kettles
}

Continuous process, as well as refining capacity of lead is highly dependent on the quality of kettles for refining lead. The kettles are made from special kettles plate and are generally spherical in shape. Quality kettle plate, the method of construction of the kettle, the kettle operation mode, proper maintenance regime technological refining process is represented by factors of which depends on the overall lifetime of the kettle. The quality of the welding electrode and method significantly influences the lifetime of the kettle, not only in the preparation of the kettle, but also in its reparation.

Keywords: lead refining, kettle,construction, exploitation, life time.

\section{INTRODUCTION}

The lenght of service and the repair of kettles for refining represent one of the most serious problems in each lead refinery.

In lead, during the refining, some corrosiveactive elements (zinc, sulphur, arsenic etc.) are present, etching the kettle sides.

The presence of zinc is especially dangerous in the interval of $500-510^{\circ} \mathrm{C}$, so that it is necessary to avoid these temperatures.

Besides the loading of lead mass, changes of temperatures and corrosive activity of the melted lead over the whole surface of the kettle, there are, during refining, the local loadings, local overheatings and corrosive influences that could considerably reduce the kettle lenght of service. After a certain period of time, the kettle sides crack, but by the successful welding of the cracks, the kettle is ready for use again. By the high quality repair, that means the welding of kettle sides cracks as well as correct exploitation, one kettle can be used several years, after some more or less important repairs. The kettle lenght of services after the first repair should be much longer than the time from beginning of the kettle service till its first repair.

Altough the kettle quality depends a lot on its sheet quality, the two main causes influencing the kettle-life time are:

- high-quality construction of kettle, and

- way of exploitation o kettle.

The constructor of kettle must know the lead refining process, as well as possible variances of this process.

\section{KETTLE CONSTRUCTION}

Generally, there are two types of kettle construction: spherical and cylindrical, Figure 1, and table 1, and depending on the kettle type, the type of firebox should constructed. For both types it is necessary to take into consideration that it is desirable that the kettle has as small as possible welds (joints), because the experiance has proved that the most damages of kettle appear on the welds, and not on the sound part of kettle sheet.

Table 1 - Basic dimensions of kettle for lead refining, $\mathrm{mm}$

\begin{tabular}{|l|rrr|rrr|}
\hline \multirow{2}{*}{ Parameter, mm } & \multicolumn{6}{|c|}{ Kettle capacity, tones of lead } \\
\cline { 2 - 8 } & \multicolumn{4}{|c|}{ Spherical type } & \multicolumn{3}{c|}{ Cylindrical type } \\
\cline { 2 - 7 } & 100 & 150 & 280 & 100 & 150 & 280 \\
\hline Internal diameter of kettle & 3000 & 3500 & 4115 & 2990 & 2990 & 3600 \\
\hline External diameter of kettle & 3500 & 4000 & 4623 & 3350 & 3350 & 3800 \\
\hline Maximal depth of kettle & 1925 & 2150 & 2819 & 1850 & 2450 & 2865 \\
\hline Thickness of kettle sheet & 32 & 32 & 32 & 30 & 30 & 40 \\
\hline
\end{tabular}

Author'address: ${ }^{1}$ Engineering academy of Serbia, Belgrade, University of Belgrade, Faculty of Technology and Metallurgy, Belgrade, ${ }^{3}$ Institute for Chemistry, Technology and Metallurgy, Belgrade, Serbia
Received for Publication: 12. 05. 2014.

Accepted for Publication: 23. 07. 2014. 

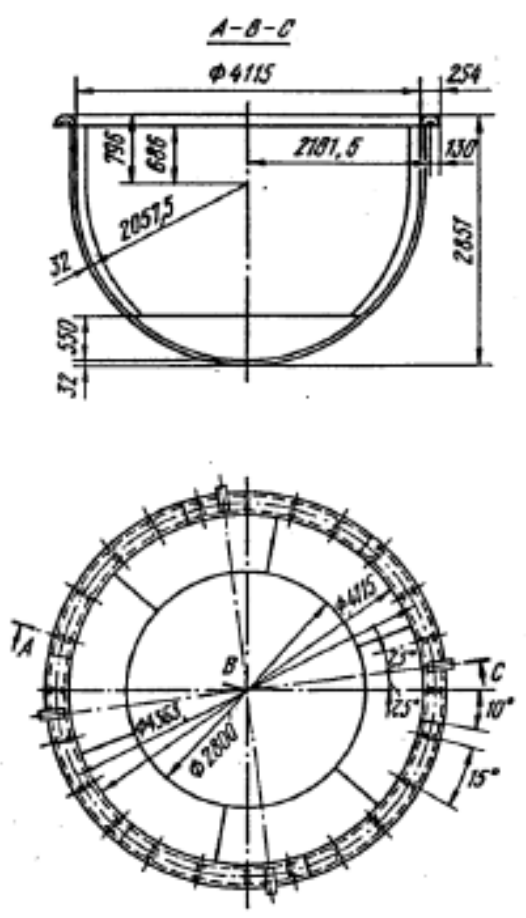

Spherical type

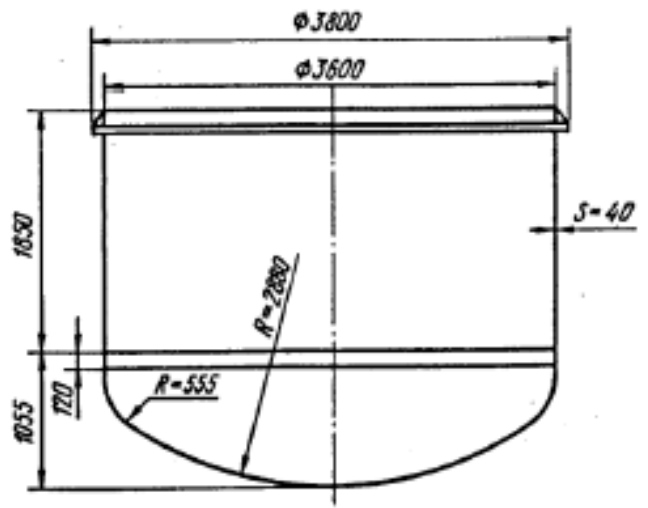

Cylindrical type

Figure 1 - Kettle for lead refining, capacity $280 t(\mathrm{~mm})$

That means that the kettle constructors have to pay more attention to the type electrodes choice and technique of welding, and not only to the kettle sheet quality.

The thickness of the kettle sheet varies from 32 to $45 \mathrm{~mm}$ and there are two main factors influencing on the choice of the thickness:

- smaller thickness, the kettle heating is faster, the heat conducting is faster, but also the mechanical resistance of kettle is reduced, that means that the kettle carrying capacity is reduced,

- as the thickness of kettle sheet increases, the heating of lead in kettle is more difficult, temperature shocks are bigger and the kettle carrying capacity increases.

Applying the higher quality kettle sheet and higher quality construction of kettle, the carrying capacity of kettle and smaller thickness of kettle sheet are justified.

On the top of kettle there is ring surface leaning on the wall of the firebox. The ring and the ribs have the function of supporting structure so that their construction and form depend on the kettle capacity.

The construction of firebox depends on the type of kettle and the type and quality of fuel. During the construction of the firebox, the special attention has to be payed to the following fact:
- the lead refining has several technological operations carried out on the temperatures of $335^{\circ} \mathrm{C}$ (final decoppering) to $650{ }^{\circ} \mathrm{C}$ (vacuum dezincing).

In this range of temperature, the extension of kettle during operation will be different so that the kettle must be leaned on the firebox or support (segment of sphere) depending on the firebox type. The kettle is mainly extended on the top part or on the very bottom, and there are some cases that the kettles work after the succesful repairs with one, two and even three deformations because of extension.

There ares some cases of double deformations on the bottom of kettle:

- extension and counter „thrust“ of support from firebox, and the kettle still works, although on the lower working temperatures.

The kettle deliverer should anneal the produced kettle in the furnace for annealing, for homogenization of the kettle sheet and welds.

\section{KETTLE EXPLOITATION}

One of the determining factors of the long duration of kettle is the beginning of its exploitation, that means its putting into operation and processing of the first two to three melting of lead in kettle.

The manufacturer should anneal the kettle in the annealing furnace, because the local annealing of welds by electroheaters cannot replace the furnace for annealing. 
The kettle should never be warmed up when it is empty. If it is necessary to warm up the empty kettle, pour previously the water to avoid the local overheating of sheet. If it is available, the best is to put some pieces of lead so that there is a layer of metal in the kettle during heating. It is desirable always leave on the bottom of kettle one layer of lead during its transfer into the other kettle, so that the next heating of the kettle would be more uniform.

The speed of kettle heating is very important. The kettle loaded with lead not be heated by a speed over $50{ }^{\circ} \mathrm{C} / \mathrm{h}$. This speed of heating should be determined by the kettle constructor, although it depends also on the specific states (if the kettle is full, what is the temperature at the beginning and at the end of heating).

In some operations (decoppering, desilverizing, debismuthing) during the cooling, some stickings (metal compunds) are separated from the melted lead on the interior sides of kettle. These stickings should be eliminated during the operation by the long bars, that means the interior sides of kettle must be cleaned, because these stickings reduce the heat conducting and provoke the local overheating of the kettle sides.

During the operation it is necessary to check and possibly to repair the supports (braces, segment of sphere) in the firebox on which the kettle is leaned on during the temperature extensions. The designed distance (clearence) between the kettle and firebox should be maintained during the kettle exploitation. This distance varies for different temperatures, that means for different technological operations of lead refining process.

It is normal that the most sound kettle is used for the most difficult technological operations, while the repaired kettles are intended for easier operations on lower working temperatures (final desilverizing, debismuthing, final refining).

The kettle life - time should be expressed by time (number of hours in operation), according to the number of meltings and technological operations carried out in the kettle. The presentation with only one factor doesn't present the reliable proof of the kettle quality.

The quality of the kettle repair, that means the quality of electrodes and welding of cracks of the kettle sides (sheet) has the great influence on the total life time of the kettle.

By the recording of damaged sheet, the size and type of sheet cracks must be stated. By cleaning, previous treatment of cracks and by succesful welding of cracks, the kettle is enabled for further exploitation. By the succesful repairs the kettles could have the life-time even several years.

\section{CONCLUSION}

The quality and service life of the kettle depends on the type and quality of kettle sheet, welding electrodes and welding quality when connecting sheet i.e. construction of the kettle. However, the service life significantly depends on the exploitation conditions of the kettle and the variable process parameters.

In practice, it is often forces the velocity of the refining process in order to increase the production. However, this increase in production should be in accordance with the prescribed conditions of exploitation of the refining kettles.

\section{REFERENCES}

[1] R. Vračar, B. Nikolić (1995): Ekstraktivna metalurgija olova, Monograph, Ed. Naučna knjiga, Beograd

[2] Ф. М. Лоскутов (1965): Металлургия свинца, Изд. Металлургия, Москва

[3] B. Nikolić (1991): Bakar u metalurgiji olova, Monografija, Ed. Građevinska knjiga, Beograd

[4] B. Nikolić (2004): Antimon u metalurgiji olova, Monograph, Ed. IHTM, Beograd

[5] B. Nikolić i saradnici (2007): Hemijsko-tehnološki priručnik, JINA, Beograd

[6] B. Nikolić, D. Vučurović, S. Ostojić (2002): Metalurgija obojenih metala Jugoslavije krajem XX veka, IHTM, Beograd

\section{IZVOD}

\section{FAKTORI KOJI ODREĐUJU RADNI VEK KOTLOVA ZA RAFINACIJU OLOVA}

Kontinualni proces, kao i kapacitet rafinacije olova veoma zavisi od kvaliteta kotlova za rafinaciju olova. Kotlovi se izrađuju od specijalnog kotlovskog lima i uglavnom su sfernog oblika.

Kvalitet kotlovskog lima, način konstrukcije kotla, način eksploatacije kotla, pravilno održavanje režima tehnološkog procesa rafinacije predstvaljaju faktore od kojih zavisi ukupni radni vek kotla. Način zavarivanja $i$ kvalitet elektroda bitno utiču na radni vek kotla, ne samo pri izradi kotla, nego $i$ pri njegovoj reparaciji.

Ključne reči: rafinacija olova, kotao, konstrukcija, eksploatacija, radni vek.

Stručni rad

Primljeno za publikovanje: 12. 05. 2014.

Prihvaćeno za publikovanje: 23. 07. 2014. 